\title{
HOMENAGEM A GILBERTO TINETTI: VILLA-LOBOS, CAMARGO GUARNIERI, ELGAR E BRAHMS
}

Antonio Vaz Lemes ${ }^{1}$

RESENHA - TINETTI, Gilberto. Homenagem a Gilberto Tinetti I e II. CD de áudio. LAMI-013 e LAMI-014. São Paulo: LAMI-ECA/USP, $2013^{2}$.

O jovem pianista Gilberto Tinetti retorna ao Brasil, em 1960, após um período de três anos de aperfeiçoamento na Europa. Soma seus vinte e oito anos. No mesmo ano, a convite do compositor Camargo Guarnieri, grava na rádio MEC do Rio de Janeiro suas Sonatinas para piano. O compositor, no alto de seus cinquenta e três anos, vive a plenitude de sua maturidade artística, tendo escrito recentemente sua Quarta Sonatina para piano.

Por que Tinetti privilegia portanto a forma sonata? Por que uma "integral"? Por que Guarnieri? As respostas parecem óbvias, mas temos na decisão artística de registrar todas as Sonatinas muito sobre a índole musical deste pianista. Independente dos caracteres das obras, divagamos sobre seu precoce comprometimento com a tradiçáo e o equilíbrio, com a reverência artística e a diplomacia. Imagina-se seu entusiasmo, prevendo nas dimensóes de uma radiodifusão a bela oportunidade para apresentar seu trabalho ao grande público. Segundo ele, "a Primeira e a Quarta Sonatinas eu já havia aprendido antes mesmo de ir para Paris. Para a gravação da rádio, aprendi a Terceira, bastante popular na época, mas também a Segunda, que até hoje é rarissimamente tocada".

A audição destas gravações retorna ao público, em formato de CD, graças ao lançamento da "Homenagem a Gilberto Tinetti volumes I e II" (Selo LAMI-USP), que ainda disponibiliza a interpretaçáo do Concerto para piano n. 4 de Villa-Lobos (gravado na França em 1970), além de regis-
1. Mestre em Música pela Universidade Estadual Paulista (UNESP). Email: antoniovazlemes@gmail. com.

2. LAMI013 -

HOMENAGEM A GILBERTO TINETTI

I: CD em comemoração aos 80 anos do pianista Gilberto Tinetti, com o Quinteto em Lá menor para piano e cordas, Op. 84, de Edgar Elgar e o Trio para piano, clarinete e violoncelo, op. 114, de Brahms. Betina Stegmann e Nelson Rios (violinos), Marcelo Jaffé (viola), Robert Suetholz (violoncelo), Gilberto Tinetti (piano) e Luiz Afonso Montanha (clarinete). LAMI014 - HOMENAGEM A GILBERTO TINETTI

II: CD em comemoração aos 80 anos do pianista Gilberto Tinetti, apresenta uma das raras gravaçóes do Concerto para piano No 4 de Villa Lobos, realizada ao vivo em Paris com a Orquestra Filarmônica da Radio e Televisão Francesa (ORTF) em 1970. O CD traz ainda restauraçóes das 4 primeiras Sonatinas para piano de Camargo Guarnieri. 
tros atuais de Elgar (Quinteto para piano e cordas op. 84) e Brahms (Trio op. 114).

A audição do repertório brasileiro deste lançamento ganha especial sabor por revelar momentos particulares de convivência entre o pianista e os compositores. Com impressionante vivacidade de memória, Tinetti diverte-se descrevendo situaçóes, sem dispensar detalhes ou mesmo imitaçóes, por exemplo, do sotaque e do "timbre agudo da voz de Guarnieri”. O conjunto destas memórias merecem o carinho de qualquer aficionado pela música de Guarnieri ou Villa-Lobos. As histórias são tão especiais que lamentamos inclusive não ver neste lançamento nenhuma obra de Francis Poulenc (1899-1963), compositor com o qual Tinetti também se relacionou em Paris.

Nos anos cinquenta, enquanto vive em Paris, é por meio de uma carta enviada por Guarnieri que Tinetti recebe as atualizaçóes sobre a renovação de sua bolsa de estudos, fornecida pelo Ministério da Educação e Cultura (que ainda eram fundidos). A carta também é especialmente marcante por vir acompanhada de um comentário espirituoso sobre seus Ponteios para piano, em Guarnieri dizia: "Ontem escrevi o meu Ponteio de número cinquenta... Agora chega!”. Em outra ocasião, em 1958, também em Paris, Tinetti vai buscar Camargo Guarnieri na Aerogare des Invalides acompanhado pelo pianista José Eduardo Martins: "Lá pelas nove da noite, com o voo atrasado, vimos Guarnieri se aproximando por um corredor, mas caminhando com dificuldade - coisa que quando o deixamos aqui no Brasil [José Eduardo se mudou para a Europa mais ou menos na mesma época que Gilberto Tinetti] não existia, ele andava muitíssimo bem". Sobre o andar "diferente", o próprio Guarnieri comentou que: "Durante o vôo da AirFrance, meu vizinho de poltrona tinha comprado uma garrafa de whisky, mas só quis tomar um pouquinho... e me deu o resto!”. Na noite seguinte seria o aniversário do Guarnieri, e o musicólogo e folclorista brasileiro Luís Heitor Corrêa de Azevedo (1905-1992) faria uma recepção em homenagem ao compositor.

Também sobre a obra de Guarnieri, vale a pena retratar dois episódios curtos sobre o Ponteio n. 49. Em primeiro lugar, uma orientação interpretativa passada pelo próprio compositor ao pianista. Segundo Tinetti, o compositor "não 
queria que se fizesse nenhum rallentando no final!". Depois, Tinetti conta que, em uma aula pública, assistiu alguém tocar este Ponteio. E ao chegar no acorde final, ouve uma senhora, sentada atrás dele, lamentar: "Ah, que pena... Esbarrou!". Trata-se de um acorde de Dó menor, com sétima maior e sexta menor. É interessante relacionar a percepçáo auditiva desta senhora, como um filtro auditivo de toda uma época, ainda se acostumando com os coloridos dissonantes da música de Guarnieri.

Sobre o já famoso encontro de Tinetti e Villa-Lobos em Paris, recolho detalhes interessantes, que talvez ainda não sejam de domínio público. Tinetti foi ao encontro do compositor por conta de uma correpetição particular, que faria a uma colega russa, Nadia Gedda-Nova (que teria sido esposa do grande tenor Nicolai Gedda) em um estúdio da Salle Gaveau. Ela tocaria a parte solista do Quinto Concerto de Villa-Lobos. No dia da apresentaçáo, Tinetti chega mais cedo e já encontra Villa-Lobos acompanhado por sua esposa "Mindinha” (Arminda Villa-Lobos). Já sua colega, se atrasa. Neste descompasso, o compositor pergunta: "Você náo toca nada meu?", e Tinetti ataca o Prelúdio das Bachianas Brasileiras n. 4. A partir desse encontro com o compositor, Tinetti registra orientaçóes interpretativas valiosas: primeiro, a valorização dos baixos em oitavas (segundo Tinetti, Villa-Lobos teria dito: "Aí está o Bach!"). Já no início da segunda página, na sequência descendente e modulante do tema Villa-Lobos "pediu que eu acelerasse um pouco".

De Villa-Lobos, a Homenagem a Gilberto Tinetti vol. 1 possui a gravaçáo ao vivo da primeira audição européia do Quarto Concerto para piano e orquestra. Perguntando sobre o que o levou a se aproximar justamente deste concerto, Tinetti conta que o ouviu pela primeira vez durante um concurso nacional de piano em Santa Maria, Rio Grande do Sul, da qual foi jurado. $\mathrm{O}$ concurso privilegiava a música de Villa-Lobos e, na prova final, o pianista Paulo Gori apresentou o Quarto Concerto: "Eu fiquei com aquilo na cabeça". No final dos anos sessenta ele também aprende o Concerto e o apresenta em várias ocasiōes não apenas no Brasil, mas também em Bogotá, Lisboa e, finalmente, em Paris, de onde temos a gravação junto da Orquestra Filarmônica da Rádio Francesa, dirigida pelo Maestro Jean Fournet. 
A escolha do Trio de Brahms no repertório camerístico deste lançamento (com Luís Montanha e Robert Suetholz) vem coroar a experiência de toda uma vida dedicada à obra deste compositor. Junto ao Trio Brasileiro, Tinetti executou a integral de seus trios. $\mathrm{O}$ primeiro concerto e uma seleçáo de Intermezzi acompanham-no fielmente em seu repertório solístico. Além disso, também pude conferir apresentaçóes de vários Lieder, da Sonata para clarineta e do quinteto para piano e cordas op. 34. Já a escolha do quinteto de Elgar (com Ensemble SP) - raramente executado, inclusive na Europa, é inusitada. A oferta de uma obra pouco conhecida, mas de um compositor bemquisto entre os violoncelistas (seu famoso concerto para violoncelo op. 85), ou mesmo pelos músicos de orquestra (por suas Variaçóes Enigma op. 36), demonstra como Tinetti sabe incitar diplomaticamente a curiosidade entre os músicos.

A profissionalização atual, inclusive na música, inspira o privilegio às especializaçóes. Hoje vemos músicos marcando sua trajetória especificamente por repertório, formação, estilo ou mesmo por determinado compositor. Ao contrário dessa tendência, temos neste lançamento "Homenagem a Gilberto Tinetti volume I e II" um retrato de um profissional múltiplo, de versatilidade rara, combinando mesma desenvoltura de acabamento impecável no repertório solístico, camerístico e sinfônico. 